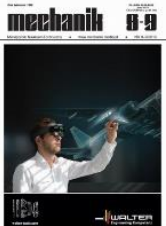

\title{
Comparison of vertical milling centers geometric errors with different time of machining
}

\author{
Porównanie błędów pionowych centrów frezarskich \\ o różnym okresie eksploatacji
}

\author{
TOMASZ JANKOWSKI \\ WOJCIECH BORKOWSKI \\ PAWEK PIÓRKOWSKI \\ ANDRZEJ ROSZKOWSKI \\ WACŁAW SKOCZYŃSKI *
}

Presented are the results of diagnostic tests for three 3-axis vertical milling centers at various operating times in the conditions of a manufacturing company. An error analysis was carried out. Machine tool evaluation was made on the basis of error values and their suitability for carrying out machining tasks in the enterprise was determined.

KEYWORDS: milling machine center, geometric accuracy tests, QC10 Ballbar, roundness deviation, machine diagnostics

Modern production systems, using automation, robotization and computerization of technological processes, combined with modern forms of production organization, allow to achieve high efficiency, flexibility, quality and economic efficiency of production. Such an effect can be obtained on condition of maintaining the proper technical condition of machines and devices by preventing the processes of wear of their components and minimizing this wear, as well as adopting an appropriate strategy of activities related to the maintenance of the operated group of devices. The source of information on the state of machinery and equipment is technical diagnostics [10].

Diagnostics of machine tools are the basis for their reliable and accurate operation. Demand for it is growing along with the globalization of production, increasingly stronger competitiveness and the required high flexibility of production. An important element of this trend is the desire to increase machining accuracy. This in turn raises the requirements for the machine tool $[1,3]$.

The types of diagnoses can be distinguished according to many criteria and functions of machining systems, the degree of organization and time of occurrence [2]. The immediate-periodic diagnosis (operational diagnostics) is the basic form of machine controlling at the stage of their operation.

Periodic diagnostics has three main tasks [10]:

\footnotetext{
* Dr inż. Tomasz Jankowski (tomasz.jankowski@pwr.edu.pl), mgr inż. Wojciech Borkowski (wojciech.borkowski@pwr.edu.pl), mgr inż. Paweł Piórkowski (pawel.piorkowski@pwr.edu.pl), dr inż. Andrzej Roszkowski (andrzej.roszkowski@pwr.edu.pl), dr hab. inż. Wacław Skoczyński prof. PWr (waclaw.skoczynski@pwr. edu.pl) - Katedra Obrabiarek i Technologii Mechanicznych, Wydział Mechaniczny Politechniki Wrocławskiej
}

- provides accurate information on the state of the machine during the scheduled time for periodic inspection, allows to determine the scope of activities necessary to restore its full efficiency and accuracy,

- enables forecasting of further diagnostic and corrective actions,

- enables to define the way of modernizing diagnosed objects and methods of diagnosing.

In this work, the results of diagnostic tests of three threeaxis CNC milling machines will be presented at various operating times in the conditions of a manufacturing company. Diagnostic tests were performed using the QC10 Ballbar system.

The purpose of the described activities, apart from verification of the technical condition of machine tools after various operational periods, is the use of this knowledge for planning and allocating production tasks with diverse requirements of dimensional and shape accuracy of the manufactured products.

\section{Measuring system}

The Ballbar QC10 system from Renishaw was used to carry out the measurements - one of the most popular solutions for the evaluation of machine tools errors in the industry $[4,9]$. The main element of this system is a precise measuring transducer (kinematic ball rod), enabling accurate measurement with a high resolution of the circle radius during circular motion (fig. 1), allowing determination of roundness deviation in interpolated circular motion, according to the norm regulating the test code for machine tools- PN ISO 230-4 [5, 6, 8].

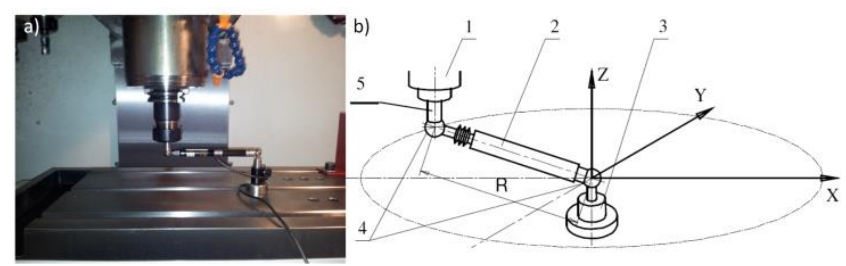

Fig. 1. Renishaw Ballbar QC10 diagnostic system: a) device installed on the milling table, $b$ ) test principle [4]: 1 - milling spindle, 2 - measuring transducer, 3 - magnetic centering stand, 4-spherical ends, 5-magnetic holder 
To carry out this test, it is necessary for the machine to move with circular interpolation in the $X Y$ plane by an angle of $720^{\circ}$ in the clockwise direction, and then the same movement in the counterclockwise direction. Movement in both directions is divided into three phases. The first $180^{\circ}$ represents the run-up phase, another $360^{\circ}$ - the main measurement phase with a constant feed rate, and the last $180^{\circ}$ is the run-out phase.

Similar tests can be carried out in the $X Z$ and $Y Z$ planes, but on an arc limited to a maximum of $220^{\circ}$, which results from the construction of a vertical three-axis milling machine.

By means of the Renishaw software, apart from the already mentioned roundness deviation, it is possible to determine other component errors: geometrical errors, dynamic errors and clearances.

\section{Experiment plan}

The main purpose of the conducted tests was the identification and quantification of accuracy errors of the group of CNC machine tools used in the manufacturing enterprise of the machine industry. Information on the values of measured errors can be used to select the appropriate machining tasks that will be performed on the tested machines during their further operation. An attempt was made to link the measured errors to the working time of the machine tools and the type of machining that was most often performed on them.

Three three-axis vertical milling centers from Haas were selected for the tests: VF-7/50, VF-6/50 and VF-3YT/50, with analogous kinematic structure and spindles with the same structure and characteristics (fig. 2). The basic technical data of machine tools is presented in the table.

The VF-7/50 milling machine was mainly used for shaping and finishing work, and during its operation the spindle load was within $30 \div 50 \%$ of the maximum permissible values.

The main task of the VF-6/50 milling machine was to perform roughing. The spindle load during this type of machining varied between 70 and $90 \%$.

The VF-3YT/50 milling machine was only operated for two months and was mainly used for training purposes, for making short series of items. The spindle load during its operation did not exceed $40 \%$ of the permissible values.

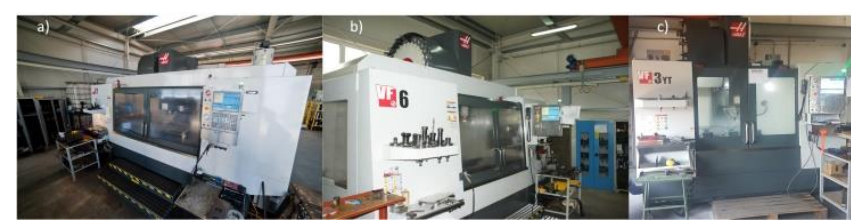

Fig. 2. Tested milling centers: a) VF-7/50, b) VF-6/50, c) VF-3YT/50

It was decided to carry out measurements at the central point of the table of each machine. This part of the working space of the machine tool is most often used for fixing the workpiece, moreover, the choice of the central point of the table allows the use of ball bars of several different lengths.

To perform the tests, a ball rod of three lengths $(L)$ was used: 100,150 and $300 \mathrm{~mm}$ - i.e. all, where it is possible to make a full circle in the working space of machine tools.

It was determined that the measurements will be made for the following values of linear feedrate $\left(V_{f}\right): 1000,3000$, $6000 \mathrm{~mm} / \mathrm{min}$.

This selection of the length of the ball bar and the value of the feed speed resulted from the fact that the percentage of particular types of errors in the total error of roundness depends on the radius of the circle plotted by the ball bar and the speed at which this movement is performed. When making measurements at high speed, the errors of roundness are mainly determined by dynamic errors. When the measurement is carried out at a low speed, the geometry of the machine has a greater influence on the roundness deviation value.

It was planned to measure the following values using the Ballbar QC10 diagnostic system: roundness deviations, $X$ axis error, $Y$ axis error, squareness deviation, positioning difference, $X$ axis backlash and $Y$ axis backlash. Measurements were made only in the $X Y$ plane.

TABLE. Basic technical data of the tested machines

\begin{tabular}{|l|c|c|c|}
\hline $\begin{array}{l}\text { Milling } \\
\text { machine } \\
\text { model }\end{array}$ & Machine 1 & Machine 2 & Machine 3 \\
\cline { 2 - 4 } & VF-7/50 & VF-6/50 & VF-3YT/50 \\
\hline $\begin{array}{l}\text { Spindle } \\
\text { power, kW }\end{array}$ & 22.4 & 22.4 & 22.4 \\
\hline $\begin{array}{l}\text { Max. spin- } \\
\text { dle speed, } \\
\text { rpm }\end{array}$ & 7500 & 7500 & 7500 \\
\hline $\begin{array}{l}\text { Year of } \\
\text { production }\end{array}$ & 2010 & 2015 & 2017 \\
\hline $\begin{array}{l}\text { Work time, } \\
\text { h }\end{array}$ & 6302 & 2444 & 103 \\
\hline
\end{tabular}

\section{Analysis of results}

For each of the three tested machine tools, roundness values were determined for nine combinations of parameters: kinematic rod length and feed speed values (fig. 3). The results show significant differences between the tested machines, which may indicate the diversification of the technical condition and the degree of wear of the assemblies and machine components.

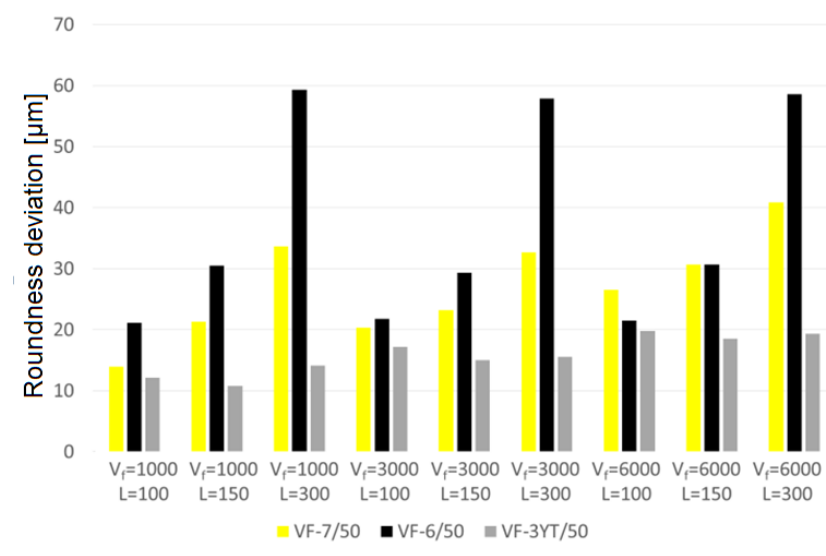

Fig. 3. Results of roundness deviation measurements as a function of the kinematic rod length $(L, \mathrm{~mm})$ and linear feed rate $\left(V_{\mathrm{f}}\right.$, $\mathrm{mm} / \mathrm{min}$ ) for the three tested machines

Roundness deviations for the VF-7/50 machine reach values from 13.9 to $40.9 \mu \mathrm{m}$. These values increase with increasing the length of the ball bar and the feed rate. Roundness deviations for the VF-6/50 machine obtained values from 21.1 to $58.6 \mu \mathrm{m}$, and on this machine the errors in all measurements reached the highest values. The roundness deviation for the VF-3YT/50 machine reached values from 12.1 to $19.8 \mu \mathrm{m}$ and these were the lowest error values compared to analogous measurements for other machines.

The results of the measurements show some dependencies (fig. 3). Circular deviation values for machines 1 and 2 are very sensitive to the change in the length of the ball bar. With the increase of this length, the value of total deviation increases. Such a dependence does not occur for machine 3 . In contrast, it depends on the feed rate, which is visible for machines 1 and 3 , but it is not visible for machine 2 . 
The component errors analysis focuses on the most significant errors, i.e. having the greatest impact on the value of the total deviation of roundness. These are: return error, deviation perpendicularity, difference in position deviation and backlash.

In the results of the VF-7/50 machine measurements, a relationship was observed in that for the shorter lengths of the ball bar and higher feed speeds, dynamic errors predominate, mainly the error of the $X$-axis $(30 \%)$ and $Y$ axis $(5 \%)$. However, along with increasing the length of the ball bar and decreasing the linear feed rate, the value of dynamic errors decreases, and the value of geometry errors increases, especially deviations of the axis perpendicularity $(14 \%)$ and the difference in positioning deviation (32\%).

The results of the VF-6/50 machine measurements show a very large impact of axial perpendicular deviation. This error is the dominant component of the total roundness deviation $(41 \div 63 \%)$ in all measurements, regardless of the length of the ball bar and the feed rate. The results of measurements obtained for the VF-3YT/50 machine show a similar trend of the effect of dynamic errors and geometry errors.

\section{Conclusions}

Conducting regular diagnostic tests allows you to acquire up-to-date knowledge about the technical condition of operated machines. The use of this information in planning machining tasks for various machine tools enables more efficient use of all machines.

Based on experimental investigations of three machining centers with different service life and obtained error values, it can be stated that there are significant differences in the technical condition of the machines. The smallest roundness error was detected during the VF-3YT/50 milling machine measurements, while the highest error value occurred during the VF-6/50 milling machine measurements. The machine tool, although it was manufactured in 2015, exceeds the acceptable roundness deviation of $12 \mu \mathrm{m}$ and the allowable roundness deviation quoted in the literature, at which it is possible to maintain a satisfactory dimensional and dimensional accuracy of $25 \mu \mathrm{m}[5,7]$. Although the operation time of the VF-6/50 miller is more than half that of the VF-7/50 miller, the error values in the machine tool with a longer working time were lower. It can be concluded on this basis that the type of machining used and the degree of spindle load have a greater impact on the occurrence of errors in the machine tool than the machine's working time.

The VF-7/50 milling machine maintains satisfactory values of measured errors after more than 6000 operating hours and it is still possible to perform parts with satisfactory dimensional and dimensional accuracy. Compared with the VF-3YT/50 milling machine, however, it can be observed that the working time of the machine affects the deterioration of its accuracy, even if small spindle loads are used.

The conducted research allows to prepare a plan for further exploitation of the discussed machines in terms of their effective use in a production enterprise.

Due to the highest roundness deviation value, the VF$6 / 50$ milling machine should be used for roughing tasks. It is worth noting that despite the fact that the permissible error values are significantly exceeded, the machine tool can still be useful in the company without the need to calibrate it. The VF-7/50 milling machine should be used for the tasks related to the forming machining. Its roundness deviation exceeds the limits permitted by the standard, but in industrial practice, machine tools with such accuracy allow for achieving satisfactory dimensional and shape accuracy. The VF-3YT/50 milling machine, which in the study achieved the smallest value of roundness deviation, should be used for tasks related to finishing treatment. Due to the fact that roughing causes the fastest deterioration of the machine's accuracy, you should consider avoiding the use of this type of machining on new machines, unless they were purchased primarily for this purpose.

During the research, it was also possible to confirm the dependence concerning the influence of various types of errors on the total deviation of roundness. In the machines under analysis, dynamic errors, mainly axial return errors, had a decisive influence on the roundness error value during the measurement with a high feedrate of 6000 $\mathrm{mm} / \mathrm{min}$. In the case of measurements with a low feed value of $1000 \mathrm{~mm} / \mathrm{min}$, geometry errors, mainly positioning deviation and axial perpendicular deviation had a much greater impact on the total roundness error.

Presented roundness errors allow to quickly acquire knowledge about inaccuracies caused by machining tasks performed on a given machine. The data on this inaccuracy allows the machine user to take into account this knowledge when planning activities related to the selection of a suitable machine tool for performing specific machining operations. This information is useful when the enterprise has several machines of the same type that can be used to produce the same parts.

\section{REFERENCES}

1. Cempel C., Tomaszewski F. (red.). „Diagnostyka maszyn. Zasady ogólne. Przykłady zastosowań”. Radom: MCNEMT, 1992.

2. Honczarenko J. „Elastyczna automatyzacja wytwarzania”. Warszawa: WNT, 2000.

3. Honczarenko J., Kwaśniewicz J. „Nowe systemy pomiarowe do sprawdzania dokładności obrabiarek CNC". Mechanik. 12 (2008): pp. 1012-1016.

4. Jóźwik J. „Ocena odchyłki prostopadłości osi obrabiarki sterowanej numerycznie z wykorzystaniem systemu QC10 Ballbar". Postępy Nauki i Techniki. 4 (2010): pp. 91-102.

5. Jóźwik J., Pieśko P., Krajewski G. „Ocena testu QC10 do kontroli off-line obrabiarek sterowanych numerycznie". Eksploatacja Niezawodność. 3 (2010): pp. 10-20.

6. Kaczmarek J., Lange S., Święcik R., Żurawski A. „Identyfikacja błędów pionowego centrum frezarskiego za pomoca systemu Ballbar oraz ich korekcja poprzez poziomowanie obrabiarki". Mechanik. 8-9 (2015): pp. 479-487.

7. Materiały firmy Renishaw: Analiza przypadku - Systemy pomiarowe QC10 Ballbar i MT.

8. PN-ISO 230-4:1999 - Przepisy badania obrabiarek. Badania okragłości w obrabiarkach sterowanych numerycznie.

9. Turek P., Kwaśny W., Jędrzejewski J. „Zaawansowane metody identyfikacji błędów obrabiarek". Inżynieria Maszyn.15, 1/2 (2010): pp. 7-37.

10. Żółtowski B., Cempel C. (red.). „Inżynieria diagnostyki maszyn”. Warszawa-Bydgoszcz-Radom: ITE PIB, 2004.

Translation of scientific articles, their computer composition and publishing them on the website www.mechanik.media.p by original articles in Polish is a task financed from the funds of the Ministry of Science and Higher Education designated for dissemination of science.

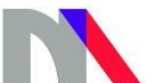

